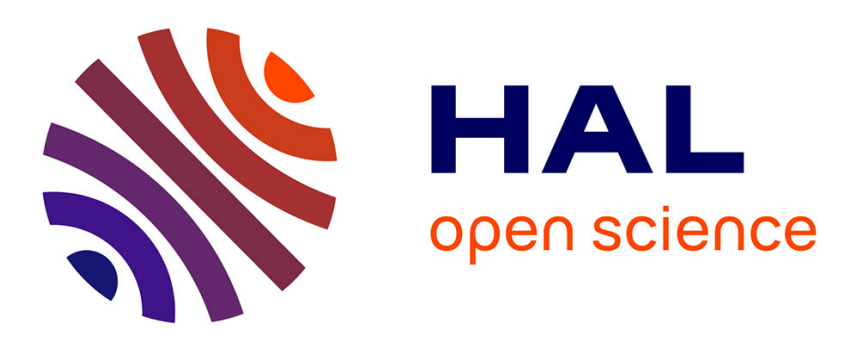

\title{
An Improved Synthesis of Ternary Carbonates: The Examples LiLa(CO3)2 and $\mathrm{La}(\mathrm{CO} 3) \mathrm{F}$
}

\author{
Hans-Juergen Meyer
}

\section{To cite this version:}

Hans-Juergen Meyer. An Improved Synthesis of Ternary Carbonates: The Examples LiLa(CO3)2 and $\mathrm{La}(\mathrm{CO} 3) \mathrm{F}$. Journal of Inorganic and General Chemistry / Zeitschrift für anorganische und allgemeine Chemie, 2010, 636 (15), pp.2622. 10.1002/zaac.201000198 . hal-00574813

\section{HAL Id: hal-00574813 https://hal.science/hal-00574813}

Submitted on 9 Mar 2011

HAL is a multi-disciplinary open access archive for the deposit and dissemination of scientific research documents, whether they are published or not. The documents may come from teaching and research institutions in France or abroad, or from public or private research centers.
L'archive ouverte pluridisciplinaire HAL, est destinée au dépôt et à la diffusion de documents scientifiques de niveau recherche, publiés ou non, émanant des établissements d'enseignement et de recherche français ou étrangers, des laboratoires publics ou privés. 


\section{An Improved Synthesis of Ternary Carbonates: The Examples $\mathrm{LiLa}(\mathrm{CO} 3) 2$ and $\mathrm{La}(\mathrm{CO} 3) \mathrm{F}$}

\begin{tabular}{|r|l|}
\hline Journal: & Zeitschrift für Anorganische und Allgemeine Chemie \\
\hline Manuscript ID: & zaac.201000198.R1 \\
\hline Wiley - Manuscript type: & Article \\
\hline Date Submitted by the \\
Author: & 15-Jun-2010 \\
\hline Complete List of Authors: & Meyer, Hans-Juergen \\
\hline Keywords: & Rare Earth, Carbonate \\
\hline \multicolumn{2}{|l}{} \\
\hline
\end{tabular}

\section{今 scholaroNE" \\ Manuscript Central}




\title{
An Improved Synthesis of Ternary Carbonates: The Examples $\mathrm{LiLa}\left(\mathrm{CO}_{3}\right)_{2}$ and $\mathrm{La}\left(\mathrm{CO}_{3}\right) \mathrm{F}$
}

\author{
Jochen Glaser, ${ }^{[\mathrm{a}]}$ and H.-Jürgen Meyer*[a]
}

Keywords: Rare earth; Carbonate; Metathesis, Crystal Structure; Luminescence

\begin{abstract}
The ternary carbonate $\mathrm{LiLa}\left(\mathrm{CO}_{3}\right)_{2}$, previously obtained under supercritical $\mathrm{CO}_{2}$ pressure conditions was prepared by a new and efficient way of synthesis. A 2:1 molar mixture of $\mathrm{Li}_{2}\left(\mathrm{CO}_{3}\right)$ and $\mathrm{LaCl}_{3}$ was reacted in a silica tube at $400{ }^{\circ} \mathrm{C}$. The crystal structure of $\mathrm{LiLa}\left(\mathrm{CO}_{3}\right)_{2}$ was refined from X-ray single-crystal data and can be related with a caesium chloride type arrangement where $\mathrm{Li}^{+}$and $\mathrm{La}^{3+}$ ions occupy the caesium positions and $\left(\mathrm{CO}_{3}\right)^{2-}$ ions occupy all cubic voids. Cerium-doped samples $\left(\mathrm{LiLa}\left(\mathrm{CO}_{3}\right)_{2}: \mathrm{Ce}\right)$ exhibit blue luminescence. The mineral bastnäsite was synthesized by the same preparative approach, departing from a 1:1 molar mixture of $\mathrm{LaF}_{3}$ and $\mathrm{Li}_{2}\left(\mathrm{CO}_{3}\right)$ being reacted at $450{ }^{\circ} \mathrm{C}$.
\end{abstract}

\footnotetext{
${ }^{*}$ Prof. Dr. H.-J. Meyer

Fax: +49-7071-29-5702

E-mail: juergen.meyer@uni-tuebingen.de

[a] Abteilung für Festkörperchemie und Theoretische Anorganische Chemie Institut für Anorganische Chemie

Ob den Himmelreich 7

Eberhard-Karls-Universität Tübingen

D-72074 Tübingen, Germany
} 


\section{Introduction}

Carbonates of the rare earth $(R E)$ elements with the expected formula $\mathrm{RE}_{2}\left(\mathrm{CO}_{3}\right)_{3}$ remain a missing group of compounds, although the chemistry of corresponding carbodiimides has been recently developed, i.e. for the formula type $R E_{2}\left(C_{2}\right)_{3}$ with $R E=Y, C e-L u$ [1]. The chemical relationship between carbodiimides and carbonates may be reflected by the synthesis of carbodiimide through ammonolysis reaction of a metal carbonate, and oppositely, by the decomposition of carbodiimide into carbonate in the presence of moist air or water, with a typical example being represented by the corresponding lithium compounds [2]:

$$
\mathrm{Li}_{2}\left(\mathrm{CO}_{3}\right)+2 \mathrm{NH}_{3}=\mathrm{Li}_{2}\left(\mathrm{CN}_{2}\right)+3 \mathrm{H}_{2} \mathrm{O}
$$

Rare earth carbonates are known as hydrates, like $\mathrm{La}_{2}\left(\mathrm{CO}_{3}\right)_{3} \cdot\left(\mathrm{H}_{2} \mathrm{O}\right)_{8}$ [3] being crystallized from aqueous solutions of $\mathrm{La}\left(\mathrm{NO}_{3}\right)_{3} \cdot 6 \mathrm{H}_{2} \mathrm{O}$ and $\mathrm{NaHCO}_{3}$. The thermal decomposition of $\mathrm{La}_{2}\left(\mathrm{CO}_{3}\right)_{3} \cdot 8 \mathrm{H}_{2} \mathrm{O}$ takes course over several steps. Unfortunately, the dioxide monocarbonate $\mathrm{La}_{2} \mathrm{O}_{2}\left(\mathrm{CO}_{3}\right) \cdot 3 \mathrm{H}_{2} \mathrm{O}^{4}$ is already formed below $150{ }^{\circ} \mathrm{C}$ to yield $\mathrm{La}_{2} \mathrm{O}_{2}\left(\mathrm{CO}_{3}\right)$ [5] near $400{ }^{\circ} \mathrm{C}$ [6]. Ammonolysis reactions of lanthanum carbonate hydrate have shown to yield lanthanum dioxide monocarbodiimide $\mathrm{La}_{2} \mathrm{O}_{2}\left(\mathrm{CN}_{2}\right)$ [7]. Therefore this preparative way has been considered inapplicable for the synthesis of anoxic carbodiimide compounds. [8]

Ternary carbonate hydrate compounds having the general formula $\operatorname{ARE}\left(\mathrm{CO}_{3}\right)_{2} \cdot \mathrm{xH}_{2} \mathrm{O}(\mathrm{A}=$ alkaline metal; RE = rare earth metal) have been already reported one-hundred years ago when their different solubilities were studied in attempt to develop a separation process for lanthanide elements. [9] A dehydration process of these compounds for the observation of non-aqueous compounds appears generally difficult, due to formation of dioxide monocarbonates $\left(\mathrm{RE}_{2} \mathrm{O}_{2}\left(\mathrm{CO}_{3}\right)\right)$.

A synthesis route for anhydrous ternary carbonates developed by Seidel and coworkers, departing from autoclave reactions of mixtures of alkali carbonates and rare earth oxalates, $\mathrm{A}_{2} \mathrm{CO}_{3}$ and $\mathrm{RE}_{2}\left(\mathrm{C}_{2} \mathrm{O}_{4}\right)_{3} \cdot \mathrm{xH}_{2} \mathrm{O}$, under 2000 bar $\mathrm{CO}_{2}$ pressure at $500{ }^{\circ} \mathrm{C}$. Reactions with $\mathrm{A}=\mathrm{Li}$ have yielded two monoclinic modifications of compounds having the general formula $\mathrm{LiRE}\left(\mathrm{CO}_{3}\right)_{2}$ $(R E=Y, L a-L u)$, but the crystal structures of these compounds are unknown. [10] Syntheses of $\mathrm{ARE}\left(\mathrm{CO}_{3}\right)_{2}$ compounds with $\mathrm{A}=\mathrm{Na}, \mathrm{K}$ and $\mathrm{RE}=\mathrm{Y}, \mathrm{La}-\mathrm{Lu}$ were also reported following this way of synthesis. [11] The effort in operating equipment and performance related with the highpressure synthesis of anhydrous carbonate compounds is due the relatively low thermal decomposition temperatures, in case of $\mathrm{LiLa}\left(\mathrm{CO}_{3}\right)_{2}$ being obtained slightly above $400{ }^{\circ} \mathrm{C}$. In this contribution a new and simple way of synthesis is described for the observation single crystalline 
$\mathrm{LiLa}\left(\mathrm{CO}_{3}\right)_{2}$. In addition, the crystal structure and luminescence behaviour of a Cerium-doped sample of $\mathrm{LiLa}\left(\mathrm{CO}_{3}\right)_{2}$ are reported

\section{Experimental Section}

\section{Syntheses}

The synthesis of $\mathrm{LiLa}\left(\mathrm{CO}_{3}\right)_{2}$ was successfully performed by solid state metathesis reaction from $\mathrm{LaCl}_{3}$ and $\mathrm{Li}_{2}\left(\mathrm{CO}_{3}\right)$ following a corresponding approach used for the synthesis of $\mathrm{LiLa}\left(\mathrm{CN}_{2}\right)_{2}$ [12] departing from $\mathrm{LaCl}_{3}$ and $\mathrm{Li}_{2}\left(\mathrm{CN}_{2}\right)$. A $1: 2$ molar ratio of starting materials, $\mathrm{LaCl}_{3}(\mathrm{ABCR}, 99.9 \%$ ) and $\mathrm{Li}_{2}\left(\mathrm{CO}_{3}\right)$ (Alfa, ultrapure) was carefully ground in an agate mortar and loaded into a dry silica tube under inert gas conditions (glove box). The absence of contaminations with oxygen or water was crucial for the success of the reaction.

The argon filled silica tubes containing the reaction mixtures (total mass ca. $200 \mathrm{mg}$ ) were flame sealed under vacuum, transferred into a tube furnace and heated at $400{ }^{\circ} \mathrm{C}$ for 12 - 24 hours. After cooling to room temperature by the natural cooling rate of the furnace, crystalline mixtures of $\mathrm{LiLa}\left(\mathrm{CO}_{3}\right)_{2}$ and $\mathrm{LiCl}$ were obtained as reaction products by X-ray powder diffraction, without a detectable side-phase. Thus, the reaction may be described following the equation:

$$
\mathrm{LaCl}_{3}+2 \mathrm{Li}_{2}\left(\mathrm{CO}_{3}\right) \rightarrow \mathrm{LiLa}\left(\mathrm{CO}_{3}\right)_{2}+3 \mathrm{LiCl}
$$

Doped samples of $\mathrm{LiLa}\left(\mathrm{CO}_{3}\right)_{2}$ :Ce were synthesised by substituting $5 \mathrm{~mol} \%$ of $\mathrm{LaCl}_{3}$ by $\mathrm{CeCl}_{3}$ and reacted under identical conditions as described before. Single-crystals of $\mathrm{LiLa}\left(\mathrm{CO}_{3}\right)_{2}$ were obtained when reacting the same $\mathrm{LaCl}_{3} / \mathrm{Li}_{2}\left(\mathrm{CO}_{3}\right)$ mixture with $(\approx 2 / 3$ equivalents $) \mathrm{KCl}$ in order to achieve an eutectic $\mathrm{LiCl} / \mathrm{KCl}$ flux [13]. Products were washed with water to remove $\mathrm{LiCl}$ and the salt flux, respectively.

The same type of reactions was successfully performed for the synthesis of $\mathrm{La}\left(\mathrm{CO}_{3}\right) \mathrm{F}$ (Bastnäsit). A corresponding 1:1 molar mixture of $\mathrm{LaF}_{3}$ and $\mathrm{Li}_{2}\left(\mathrm{CO}_{3}\right)$ was reacted in a silica tube to yield $\mathrm{La}\left(\mathrm{CO}_{3}\right) \mathrm{F}$ at $450{ }^{\circ} \mathrm{C}$, according to the equation:

$$
\mathrm{LaF}_{3}+\mathrm{Li}_{2}\left(\mathrm{CO}_{3}\right) \rightarrow \mathrm{La}\left(\mathrm{CO}_{3}\right) \mathrm{F}+2 \mathrm{LiF}
$$

\section{X-Ray Powder Diffraction}

Diffraction data were collected on a Stoe StadiP X-ray powder diffractometer using Gemonochromatized $\mathrm{Cu}-\mathrm{K}_{\alpha 1}$ radiation. The powder pattern of $\mathrm{LiLa}\left(\mathrm{CO}_{3}\right)_{2}$ was indexed monoclinically (from 27 reflections) yielding lattice parameters of $a=6.901$ (2) $\AA, b=7.842(2) \AA$, $c=8.432(2) \AA$, and $\beta=97.25(2)^{\circ}$. The powder pattern of $\mathrm{La}\left(\mathrm{CO}_{3}\right) \mathrm{F}$ (Bastnäsit) was indexed hexagonally (from 10 reflections) to yield $a=7.173(4) \AA$, and $c=9.823(6) \AA$. 


\section{X-Ray Single-Crystal Diffraction}

Transparent single-crystals of $\mathrm{LiLa}\left(\mathrm{CO}_{3}\right)_{2}$ were selected and fixed on the tip of glass fibers for a single-crystal diffraction measurement (Stoe IPDS diffractometer, graphite monochromatized Mo- $\mathrm{K}_{\alpha}$ radiation) at room temperature (Table 1). Intensities were corrected for Lorentz factors, polarisation and absorption effects. $\mathrm{LiLa}\left(\mathrm{CO}_{3}\right)_{2}$ was found to crystallize in the monoclinic space group 12/a. The structure refinement including anisotropic refinements of all atoms with the program SHELX [14] resulted in R1 $=0.0146$, wR2 $=0.0366$ for all measured X-ray intensities. Crystallographic data are given in Table 2 and selected interatomic distances are provided in Table 3.

\section{Photoluminescence Studies}

A fluorescence spectrometer (Edinburgh Instrument, FS920, equipped with a $450 \mathrm{~W}$ Xe-lamp) was used for the measurement of excitation and emission spectra, all monitored by a cooled photomultiplier tube (Hamamatsu R2658, detection range: $300-1010 \mathrm{~nm}$ ) driven in a single photon counting mode.

\section{Results and Discussion}

The development of preparative routes for the synthesis of thermally moderately stable compounds is a great temptation in preparative chemistry because thermally labile solid state compounds may be regarded as the largest missing group compounds, with potential to exhibit new or enhanced functionalities. Several examples of solid state metathesis (SSM) reactions have been already successfully performed in a temperature region between $400-600{ }^{\circ} \mathrm{C}$. [15] $A$ variety of rare earth carbodiimide compounds, i.e. those with the formula type $R E_{2}\left(C_{2}\right)_{3}$ were accomplished by SSM reactions departing from mixtures containing $\mathrm{Li}_{2}\left(\mathrm{CN}_{2}\right)$ and $\mathrm{RECl}_{3}$. Exothermic reactions are obtained above $400{ }^{\circ} \mathrm{C}$, sometimes near $500{ }^{\circ} \mathrm{C}$, depending on the individual $\mathrm{RECl}_{3}$ compound used, as can be monitored by thermo-analytic studies. The employment of a eutectic $\mathrm{LiCl} / \mathrm{KCl}$ flux (melting point: $\approx 354{ }^{\circ} \mathrm{C}$ ) has been advantageous in these reactions especially for single-crystal growth. Still lower reaction temperatures may be achieved by using an appropriate melt, or even a catalyst.

Binary rare earth carbonates that may be assigned with the expected formula $\mathrm{RE}_{2}\left(\mathrm{CO}_{3}\right)_{2}$ remain unknown to date, whereas their carbodiimide counterparts have been developed, e.g. for the already mentioned formula type $\mathrm{RE}_{2}\left(\mathrm{CN}_{2}\right)_{3}$. Thermal stabilities of most rare earth carbodiimide 
compounds range up to $650-750{ }^{\circ} \mathrm{C}$ and restrict any preparative attempt to operate below the decomposition temperature. The carbodiimide ion, which may be also assigned as dinitridocarbonate, is related with the (oxo-)carbonate ion by the same charge, by similar limited thermal stability, and by chemical transformation into each other mentioned in the introduction. Thermal decomposition studies of $\mathrm{LiLa}\left(\mathrm{CO}_{3}\right)_{2}$ have already shown a decomposition to occur slightly above $400{ }^{\circ} \mathrm{C}$. Therefore, all preparative attempts were restricted to this maximum temperature. The straight forward synthesis of a 2:3 molar mixture was successful for the preparation of pure $\mathrm{LiLa}\left(\mathrm{CO}_{3}\right)_{2}$. No excess pressure was noticeable when opening the silica vessel containing the reaction product. A reaction performed with a 2:3 molar mixture of $\mathrm{LaCl}_{3}$ and $\mathrm{Li}_{2}\left(\mathrm{CO}_{3}\right)$ targeting the composition $\mathrm{La}_{2}\left(\mathrm{CO}_{3}\right)_{3}$ yielded $\mathrm{LiLa}\left(\mathrm{CO}_{3}\right)_{2}$ plus side phases. Corresponding experiments departing from $\mathrm{LaF}_{3}$ and $\mathrm{Li}_{2}\left(\mathrm{CO}_{3}\right)$ yielded $\mathrm{La}\left(\mathrm{CO}_{3}\right) \mathrm{F}$.

The counterpart of $\mathrm{LiLa}\left(\mathrm{CO}_{3}\right)_{2}$ in carbodiimide chemistry is $\mathrm{LiLa}\left(\mathrm{CN}_{2}\right)_{2}$. The unknown crystal structure of $\mathrm{LiLa}\left(\mathrm{CO}_{3}\right)_{2}$ was refined on a single-crystal. The assignment of a monoclinic crystal system and the unit cell dimensions (Table 1) were consistent with the previously reported results. ${ }^{10}$ The crystal structure of $\mathrm{LiLa}\left(\mathrm{CO}_{3}\right)_{2}$, refined in this work for the first time can be considered to follow motif of the caesium chloride structure, in which $\mathrm{Li}^{+}$and $\mathrm{La}^{3+}$ ions are arranged to occupy positions of $\mathrm{Cs}^{+}$ions and carbonate groups occupy all cubic voids of this arrangement (Figure 1). In fact, this idealized arrangement is clearly distorted as a result of the planarity and orientation of the carbonate group to allow for different nearest neighbour interactions with cations. Lithium ions are surrounded by four carbonate groups forming a distorted $\left[\mathrm{LiO}_{4}\right]$ tetrahedron with oxygen atoms of four carbonate groups (Figure 2). Lanthanum ions are surrounded by eight carbonate groups forming a distorted square antiprismatic arrangement with their carbon atoms (Figure 2). The arrangement of carbonate groups results in two bidentate nearest neighbor interactions and six monodentate interactions via oxygen atoms, resulting in the coordination number of ten at the lanthanum atom. The carbonate ion in the structure itself appears almost planar (Table 3).

The potential of $\mathrm{LiLa}\left(\mathrm{CO}_{3}\right)_{2}$ as a luminescent material was investigated by luminescence measurement on $\mathrm{Ce}^{3+}$ doped samples of $\mathrm{LiLa}_{1-\mathrm{x}} \mathrm{Ce}_{\mathrm{x}}\left(\mathrm{CO}_{3}\right)_{2}$ with $\mathrm{x}=0.05$. The luminescence spectra of the $\mathrm{Ce}^{3+}$ doped materials are governed by an interconfigurational transition between the ground state levels $\left({ }^{2} \mathrm{~F}_{5 / 2}\right.$ and $\left.{ }^{2} \mathrm{~F}_{7 / 2}\right)$ of the $[\mathrm{Xe}] 4 \mathrm{f}^{1}$ configuration and the lowest crystal-field components of the $[\mathrm{Xe}] 5 \mathrm{~d}^{1}$ configuration. This is a spin and parity allowed transition, resulting in high oscillator strength and a short decay constant. Due to the involvement of d-orbitals into chemical bonding, the energy of the crystal-field components of the $[X e] 5 d^{1}$ configuration is a 
sensitive function of the chemical environment. $\mathrm{Ce}^{3+}$ activated luminescent materials can thus show UV, blue, green, or red luminescence, whereby the energetic position of the absorption and emission bands are determined by the crystal-field strength and the covalent character of the lattice position, where $\mathrm{Ce}^{3+}$ is localized. In case of $\mathrm{LiLa}\left(\mathrm{CO}_{3}\right)_{2}: \mathrm{Ce}$ a blue emission is observed near $410 \mathrm{~nm}$ and the excitation spectrum monitored for the emission at $400 \mathrm{~nm}$ reveals two bands located at 315 and $285 \mathrm{~nm}$ (Figure 3).

\section{Acknowledgment}

We are indebted to Dr. Helga Bettentrup and Prof. Dr. Thomas Jüstel from the University of Applied Sciences (FH Münster) in Steinfurt for recording luminescence data on $\mathrm{LiLa}\left(\mathrm{CO}_{3}\right)_{2}: \mathrm{Ce}$. 
Table 1. Crystal data and structure refinement for $\operatorname{LiLa}\left(\mathrm{CO}_{3}\right)_{2}$.

\begin{tabular}{|c|c|}
\hline Empirical formula & $\mathrm{LiLaC}_{2} \mathrm{O}_{6}$ \\
\hline Formula weight & 265.87 \\
\hline Temperature & $293(2) \mathrm{K}$ \\
\hline Wavelength & $0.71073 \AA$ \\
\hline Crystal system & monoclinic \\
\hline Space group & $12 / a$ \\
\hline \multirow[t]{4}{*}{ Unit cell dimensions } & $a=6.888(2) \AA$ \\
\hline & $b=7.853(1) \AA$ \\
\hline & $c=8.429(2) \AA$ \\
\hline & $\beta=97.24(3)^{\circ}$ \\
\hline Volume & $452.3(2) \AA^{3}$ \\
\hline Z & 4 \\
\hline Density (calculated) & $3.905 \mathrm{~g} / \mathrm{cm}^{3}$ \\
\hline Absorption coefficient & $9.393 \mathrm{~mm}^{-1}$ \\
\hline$F(000)$ & 480 \\
\hline Crystal size & $0.20 \times 0.06 \times 0.06 \mathrm{~mm}^{-1}$ \\
\hline$\Theta$-range for data collection & 3.95 to $25.91^{\circ}$. \\
\hline Index ranges & $-8 \leq \mathrm{h} \leq 8 ;-9 \leq \mathrm{k} \leq 9 ;-10 \leq \mathrm{I} \leq 10$ \\
\hline Reflections collected & 2400 \\
\hline Independent reflections & $441[\mathrm{R}(\mathrm{int})=0.0353]$ \\
\hline Completeness in $2 \Theta=25.91^{\circ}$ & $99.3 \%$ \\
\hline Refinement method & Full-matrix least-squares on $\mathrm{F}^{2}$ \\
\hline Data / restraints / parameters & $441 / 0 / 47$ \\
\hline Goodness-of-fit on F2 & 1.178 \\
\hline Final $R$ indices $[I>2 \sigma(I)]$ & $\mathrm{R} 1=0.0144, \mathrm{wR} 2=0.0365$ \\
\hline $\mathrm{R}$ indices (all data) & $\mathrm{R} 1=0.0146, \mathrm{wR} 2=0.0366$ \\
\hline Largest diff. peak and hole & 0.705 and -0.770 e. $\AA^{3}$ \\
\hline
\end{tabular}


Table 2. Atomic Coordinates and Equivalent Isotropic Displacement Parameters $\left(\AA^{2} \cdot 10^{3}\right)$ for $\mathrm{LiLa}\left(\mathrm{CO}_{3}\right)_{2}$. $\mathrm{U}_{\mathrm{eq}}$ is defined as one third of the trace of the orthogonalized $\mathrm{U}_{\mathrm{ij}}$ tensor.

\begin{tabular}{lllll}
\hline & $x$ & $y$ & $z$ & $\mathrm{U}_{\mathrm{eq}}$ \\
\hline $\mathrm{Li}(1)$ & $3 / 4$ & $0.2515(11)$ & 0 & $14(1)$ \\
\hline $\mathrm{La}(1)$ & $1 / 4$ & $0.1946(1)$ & 0 & $8(1)$ \\
$\mathrm{O}(1)$ & $-0.0634(3)$ & $0.3303(3)$ & $-0.1241(3)$ & $13(1)$ \\
$\mathrm{O}(2)$ & $0.4261(3)$ & $-0.0851(3)$ & $0.1207(2)$ & $12(1)$ \\
$\mathrm{O}(3)$ & $0.1821(3)$ & $0.4152(3)$ & $0.2025(2)$ & $14(1)$ \\
$\mathrm{C}(1)$ & $0.3963(4)$ & $-0.0581(3)$ & $0.2678(3)$ & $10(1)$
\end{tabular}

Table 3. Selected Interatomic Distances (in $\AA$ ) and O-C-O Angles (in ${ }^{\circ}$ ) for $\mathrm{LiLa}\left(\mathrm{CO}_{3}\right)_{2}$.

\begin{tabular}{lll}
\hline $\mathrm{Li}(1)-\mathrm{O}(1)$ & $1.862(4)$ & $\mathrm{x} 2$ \\
\hline $\mathrm{Li}(1)-\mathrm{O}(2)$ & $1.975(6)$ & $\mathrm{x} 2$ \\
\hline $\mathrm{La}(1)-\mathrm{O}(1)$ & $2.514(2)$ & $\mathrm{x} 2$ \\
$\mathrm{La}(1)-\mathrm{O}(3)$ & $2.517(2)$ & $\mathrm{x} 2$ \\
$\mathrm{La}(1)-\mathrm{O}(3)$ & $2.637(2)$ & $\mathrm{x} 2$ \\
$\mathrm{La}(1)-\mathrm{O}(2)$ & $2.649(2)$ & $\mathrm{x} 2$ \\
$\mathrm{La}(1)-\mathrm{O}(2)$ & $2.706(2)$ & \\
$\mathrm{C}(1)-\mathrm{O}(1)$ & $1.270(4)$ & \\
$\mathrm{C}(1)-\mathrm{O}(2)$ & $1.300(3)$ & \\
$\mathrm{C}(1)-\mathrm{O}(3)$ & $1.283(3)$ & \\
$\mathrm{O}(1)-\mathrm{C}(1)-\mathrm{O}(3)$ & & \\
$\mathrm{O}(1)-\mathrm{C}(1)-\mathrm{O}(2)$ & $121.5(3)$ & \\
$\mathrm{O}(3)-\mathrm{C}(1)-\mathrm{O}(2)$ & $121.7(2)$ & \\
\hline
\end{tabular}


Figure Captions:

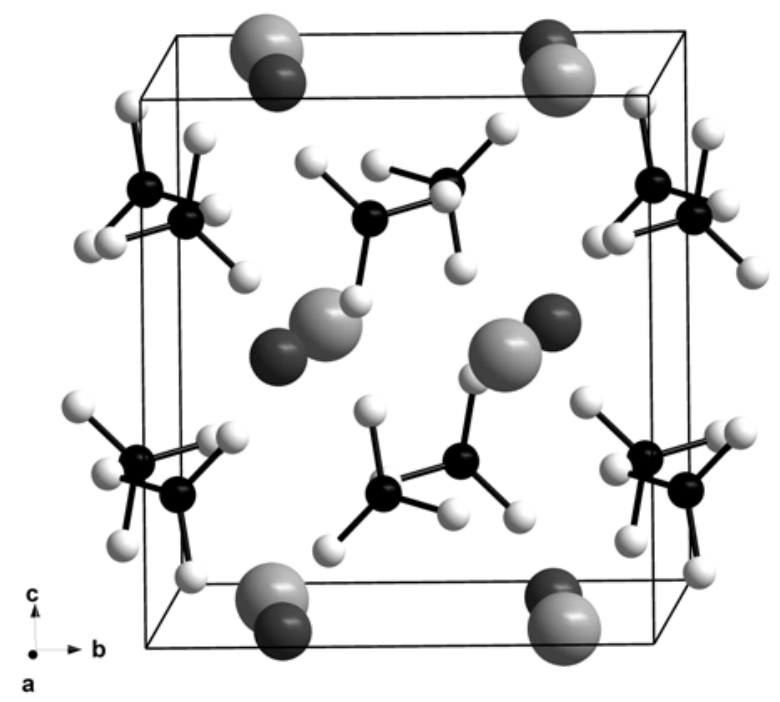

Figure 1. Projection of a section of the $\mathrm{LiLa}\left(\mathrm{CO}_{3}\right)_{2}$ structure with the unit cell shown ( $\mathrm{Li}$ ions are shown dark grey and La light grey).
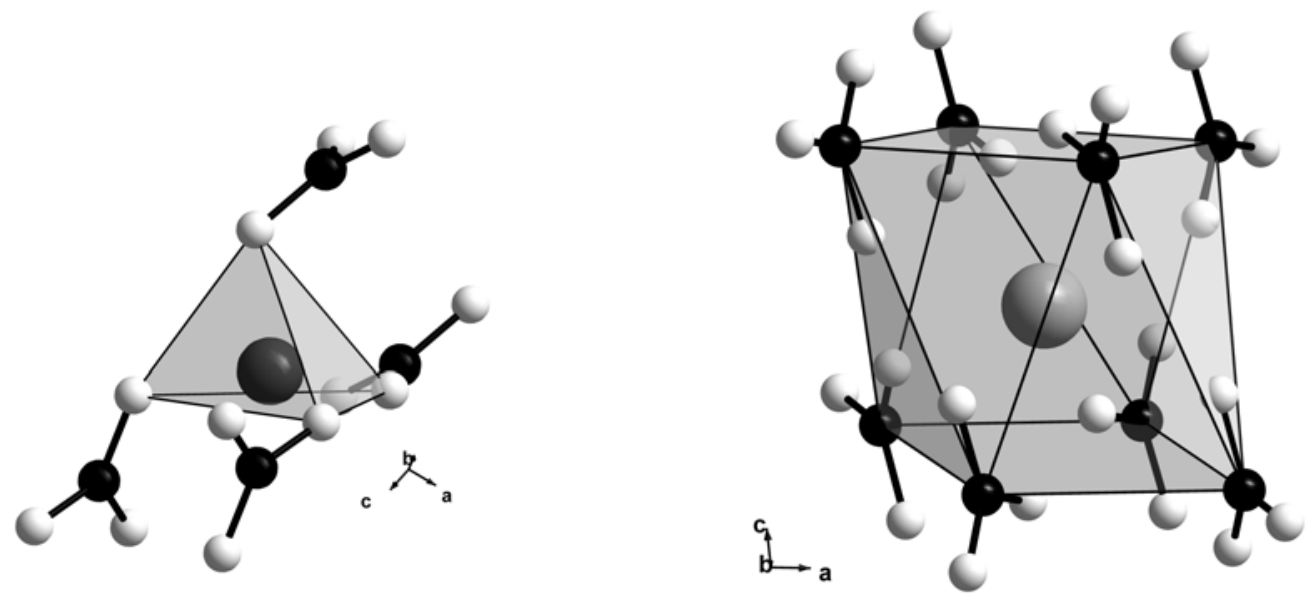

Figure 2. Arrangement of carbonate groups around lithium (left) and lanthanum (right) ions. 


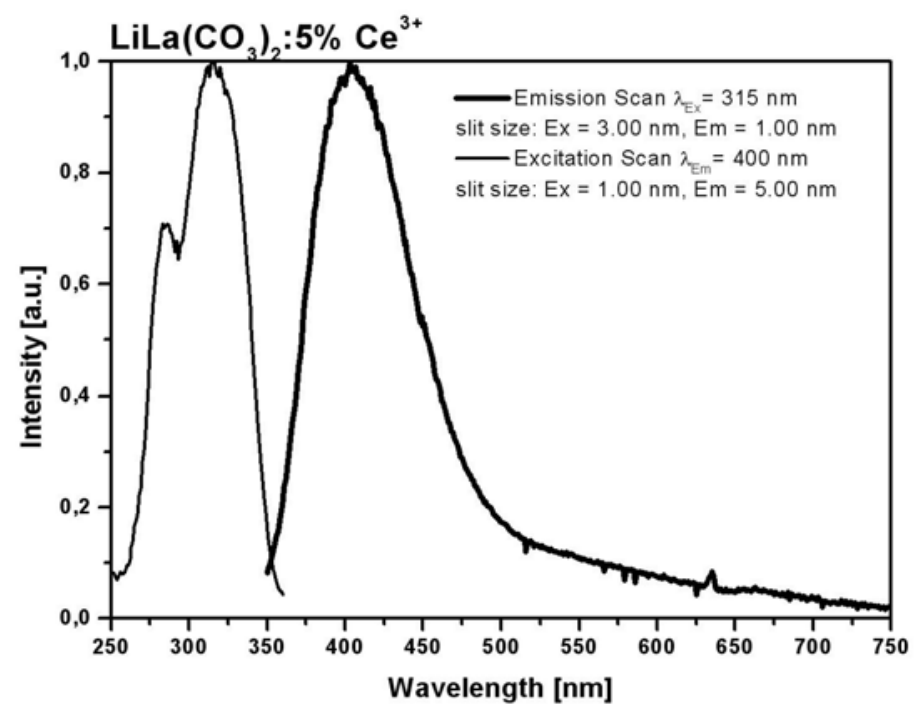

Figure 3. Excitation and emission spectrum of $\mathrm{LiLa}\left(\mathrm{CO}_{3}\right)_{2}: \mathrm{Ce}$. 


\section{References}

[1] M. Neukirch, S. Tragl, H.-J. Meyer, Inorg. Chem. 2006, 45, 8188; J. Glaser, L. Unverfehrt, H. Bettentrup, G. Heymann, H. Huppertz, T. Jüstel, H.-J. Meyer, Inorg. Chem. 2008, 47, 10455.

[2] A. Perret, BI. Soc. ind. Mulhouse 1933, 99, 10.

[3] D.B. Shinn, H.A. Eick, Inorg. Chem. 1968, 7, 1340.

[4] K. Nagashima, H. Wakita, A. Mochizuki, Bull. Chem. Sioc. Japan 1973, 46, 152.

[5] J.O. Sawyer, P. Caro, L. Eyring, Monatsh. Chem. 1972, 103, 333.

[6] K. Gibson, H.-J. Meyer, unpublished.

[7] Y. Hashimoto, M. Takahashi, S. Kikkawa, F. Kanamaru, J. Solid State Chem. 1996, 125, 37.

[8] B. Wißmann, Dissertation, Tübingen 2001.

[9] R. J. Meyer, Z. Anorg. Chem. 1904, 41, 97.

[10] H.-J. Kaltz, H. Seidel, Z. Anorg. Allg. Chem. 1980, 465, 92.

[11] H. Schweer, H. Seidel, Z. Anorg. Allg. Chem. 1981, 477, 196; H.-J. Kaltz und H. Seidel, Z. Anorg. Allg. Chem. 1982, 486, 221.

[12] L. Unverfehrt, M. Ströbele, J. Glaser, H.-J. Meyer, Z. Anorg. Allg. Chem. 2009, 635, 1947.

[13] E. Korin, L. Soifer, J. Therm. Anal. 1997, 50, 347.

[14] G.M. Sheldrick, Acta Crystallogr., Sect. A: Found. Crystallogr. 2008, 64, 112.

[15] H.-J. Meyer, Dalton Tans. 2010, in press. 